GEOFIZIKA VOL. $38 \quad 2021$

DOI: https://doi.org/10.15233/gfz.2021.38.3

Original scientific paper

(c) $(1) \circledast$

\title{
Analysis of the hydraulic connection of the Plitvica stream and the groundwater of the Varaždin alluvial aquifer
}

\author{
Igor Karlovic ${ }^{1}$, Krešimir Pavlić ${ }^{2}$, Kristijan Posavec ${ }^{2}$ and Tamara Marković ${ }^{1}$ \\ ${ }^{1}$ Croatian Geological Survey, Zagreb, Croatia \\ ${ }^{2}$ Faculty of Mining, Geology and Petroleum Engineering, University of Zagreb, Zagreb, Croatia
}

Received 4 August 2020, in final form 8 March 2021

\begin{abstract}
A combination of different statistical methods and flow duration curves was used to examine hydraulic connection between the Plitvica stream and the surrounding piezometers that capture the groundwater of the Varaždin alluvial aquifer. Also, rainfall quantities over a wider study area were considered to examine the effect of precipitation on Plitvica water levels and groundwater levels. The following statistical methods were used in this paper: the correlation method, the auto-correlation method, and the cross-correlation method. Correlation analysis show that there is generally a significant correlation between the Plitvica water levels and groundwater levels, with positive direction of the correlation. The analysis of auto-correlograms for groundwater and surface water shows that the correlation coefficient value drops below 0.2 after a longer period, which indicates a long-term memory of the system that can be explained by the slow flow and thus slow pressure transfer. Cross-correlation analyses of the time series of the Plitvica water levels and groundwater levels showed a time lag of 1-2 days with a fairly significant cross-correlation coefficient. For precipitation and groundwater levels, the relationship is much weaker, with a lag time of 4-5 days with a weak cross-correlation coefficient. The least time lag, within a day, was established between precipitation and Plitvica water levels. Analyses of the flow duration curves revealed that Plitvica almost completely drains groundwater, except in the vicinity of the piezometer 2178 where Plitvica recharges the aquifer about a quarter of the time.
\end{abstract}

Keywords: correlation, auto-correlation, cross-correlation, Plitvica stream, Varaždin alluvial aquifer

\section{Introduction}

Groundwater is an important source of drinking water for residents of Varaždin County in NW Croatia. Therefore, sustainable and efficient management of groundwater reserves in the Varaždin aquifer is vital. The groundwater 
quality concerns arise at the Varaždin aquifer due to high nitrate content. Nitrate concentrations exceeding maximum contaminant level (MCL) of $50 \mathrm{mg} / \mathrm{l}$ (as $\mathrm{NO}_{3}^{-}$) were observed at the wells of the Varaždin pumping site, resulting in closing of the pumping site. For better understanding of the nitrate distribution in the study area, a numerical groundwater flow and nitrate transport model will be developed.

The key to obtaining a useful groundwater flow model, with defining model geometry and spatial distribution of aquifer parameters, is to determine the model boundary conditions, which requires a detailed understanding of surface-groundwater (SW-GW) interaction. Karlović et al. (2021) developed a hydrogeological conceptual model of the Varaždin aquifer and defined the model boundaries. The authors analysed the head contour maps and identified that area along the Plitvica stream has insufficiently dense network of observation wells to determine its role on the recharge/discharge of the aquifer. Therefore, it is necessary to investigate the interaction between the Plitvica stream and groundwater by using another methodology for the purpose of improving the conceptual model, which will be used as a foundation for development of a numerical groundwater flow and nitrate transport model.

Several types of methods have been used to investigate SW-GW connection, such as direct measurements of water flux, mass balance approach, hydrochemical and heat tracer methods, and modelling (Li et al., 2020; Coluccio and Morgan, 2019). One of the most commonly applied techniques to explore SW-GW interaction by using time series data are statistical methods, since they are inexpensive and easy to use. The application of statistical methods provides a valuable information about the researched hydrogeological system and the aquifer dynamics i.e. the interaction between surface water and groundwater and their boundary conditions. A number of different parameters are used in statistical analyses, including water level data, rainfall, hydrochemical parameters, isotopes, and water temperatures. Posavec et al. (2017) and Posavec and Škudar (2016) applied correlation, regression and cross-correlation method on groundwater level data of the Zagreb aquifer and defined good hydraulic connection between proluvial and alluvial deposits. Chiaudani et al. (2017) used combined statistical-mathematical analysis of 24-year time series of rainfall, river level and groundwater level in central Italy, including auto-correlation, cross-correlation, and spectral analyses. According to the results, auto-correlation indicated strong memory effect for river level and groundwater level and poor memory effect for rainfall, cross-correlation analysis showed strong SW-GW interaction, while spectral analysis identified a predominant annual cycle linked to seasonal fluctuations. (Li et al., 2016) investigated shallow groundwater and river water interaction by integrating hydrochemistry and stable isotopes of water with connectivity index (CI). Marković et al. (2020) investigated the stable isotopes of water in the study area. They observed a very weak correlation of measured $\delta^{18} \mathrm{O}$ values between Plitvica stream and the waters from the piezometers 2500 and 4039 and attribute 
it to the drainage role of the Plitvica stream in this part of the aquifer. Kapuralić et al. (2018) analysed Sava River temperatures and groundwater temperatures by statistical methods of correlation and linear regression for the development of shallow geothermal energy applications. Generally, statistical methods are used both in fractured and/or karstic aquifers (e.g. Fronzi et al., 2020) and porous aquifers (e.g. Chiaudani et al., 2017), but the reliability of the methods is different. Due to the great heterogeneity of karstic aquifers, the methods are less reliable, but still the best tools to understand the aquifer dynamics in karstic environment. Alluvial aquifers are considered less heterogeneous, so the methods are more applicable and reliable, and these results can certainly be confirmed by further measurements of precipitation, flow and groundwater levels.

The main goal of this study was to investigate the hydraulic connection between the Plitvica stream and the surrounding piezometers that capture the groundwater of the Varaždin alluvial aquifer for the purpose of determining whether the Plitvica stream presents an important boundary condition for the numerical model. The following statistical methods were applied: the correlation method, the cross-correlation method, and the auto-correlation method. Time series data of rainfall, water level and groundwater level in piezometers for the period from January $1^{\text {st }}, 2016$ until December $28^{\text {th }}, 2017$ were used. This analysis will attempt to determine whether the direct impact of the Plitvica stream on the aquifer system of the Varaždin area is dominant given the impact of rainfall in the wider study area. In addition to statistical methods, Plitvica water levels and groundwater levels of surrounding piezometers were analysed using flow duration curves. The goal was to determine the extent to which the Plitvica stream drains groundwater of the Varaždin aquifer.

\section{Materials and methods}

Changing the water levels of groundwater aquifers occurs in response to changes in the boundary conditions of aquifer systems on the surface, such as river water levels or high rainfall. Groundwater levels are time series of data. Considering the cyclical nature of the processes in nature, which are measured in one hydrological year, in hydrogeological surveys, the time series of data contain from several hundred to even millions of measurements that need to be compared. Statistical analyses are therefore imposed as necessary in the study of hydrogeological processes (Posavec and Škudar, 2016). In this paper, time series of data are processed by statistical methods of correlation, cross-correlation and auto-correlation, since those are commonly used techniques for analysing output-to-input response. In addition to statistical methods, analyses of flow duration curves were used. Organization of the data, correlation analysis, flow duration curves analysis and presentation were made in Microsoft Excel (Microsoft Corporation, 2019). Auto-correlation and cross-correlation analyses and its presentation were performed using Matlab (MATLAB, 2010). 


\subsection{Correlation analysis}

The correlation, or the correlation coefficient associated with it, $r$, measures the strength of the relationship between the two variables and expresses their linear relationship (Taylor, 1997). Nothing can be inferred from the cause-effect relationship between the variables based on the correlation itself. The correlation coefficient $r$ shows the degree and direction of the correlation. The correlation coefficient does not depend on the units in which the values of the variables are expressed. The equation for the correlation coefficient is:

$$
r(x, y)=\frac{\sum_{i}\left(x_{i}-\bar{x}\right)\left(y_{i}-\bar{y}\right)}{\sqrt{\sum_{i}\left(x_{i}-\bar{x}\right)^{2}\left(y_{i}-\bar{y}\right)^{2}}}
$$

where $x_{i}$ and $y_{i}$ are data pairs while $\bar{x}$ and $\bar{y}$ are the arithmetic means of the data sample (Taylor, 1997). The value of the correlation coefficient ranges from +1 to -1 . A value of $r$ equal to +1 indicates the perfect positive coupling of the two variables. A positive value indicates the relationship between the variables $x$ and $y$, in which the value of the variable $x$ also increases with the value of the variable $y$. A value of $r$ equal to -1 indicates the perfect negative coupling of the two variables. A negative value indicates the relationship between the variables $x$ and $y$ in which, as the value of the variable $x$ increases, the values of the variable $y$ decreases. If the correlation is very weak or absent, the values of correlation coefficient $r$ are close to zero. Different authors define different levels of correlation between the values of the correlation coefficient, but all generally agree that a strong correlation between the two variables is when the correlation coefficient is $r>|0.70|$.

\subsection{Auto-correlation analysis}

The auto-correlation function defines the linear dependence of successive data values within a time series depending on their time lag (Box et al., 2008). The time series is compared with itself with a discrete increase in the time lapse, and the auto-correlation coefficient $r_{x x}(k)$ is calculated for the individual lapse times $k$ by the expression:

$$
\begin{gathered}
r_{x x}(k)=\frac{C_{x x}(k)}{C_{x x}(0)} \\
C_{x x}(k)=\frac{1}{N-k-1} \sum_{i=1}^{N-k}\left(x_{i}-\bar{x}\right)\left(x_{i+k}-\bar{x}\right) \\
C_{x x}(0)=\frac{1}{N-k-1} \sum_{i=1}^{N}\left(x_{i}-\bar{x}\right)^{2}
\end{gathered}
$$


where $C_{x x}$ is the auto-covariance; $r_{x x}(k)$ is auto-correlation coefficient; $k$ is time lag; $x_{i}$ is time series; $N$ is number of data and $m\left(r(k)=\left(r_{0}, \ldots, r_{k}, \ldots, r_{m}\right)\right)$ is the number of auto-correlation coefficients.

Various authors state different maximum values of the coefficient $m$. Box et al. (2008) propose that it be no greater than N/2, Mangin (1984) proposes N/3, and Davis (2002) N/4. Mangin introduces the term "memory effect" based on the values of the auto-correlation coefficient, which represents the time it takes for $r(k)$ to fall below 0.2 , reflecting the duration of the system response to the input pulse. The graphical representation of the calculated auto-correlation coefficients for different time lags is called an auto-correlogram.

\subsection{Cross-correlation analysis}

Cross-correlation is a statistical method that determines the degree of correlation of two time series of data. Such a comparison of time series of data provides information on the strength of the connection between the two sets as well as the time lag, that is, the time lag between the variables in the position of their maximum alignment. The cross-correlation coefficient is calculated in the same way as the linear correlation coefficient (Davis, 2002).

$$
\begin{gathered}
r_{x y}(k)=\frac{C_{x y}(k)}{C_{x y}(0)} \\
C_{x y}(k)=\frac{1}{N-k-1} \sum_{i=1}^{N-k}\left(x_{i}-\bar{x}\right)\left(y_{i+k}-\bar{y}\right) \\
C_{x y}(0)=\frac{1}{N-k-1} \sum_{i=1}^{N}\left(x_{i}-\bar{x}\right)\left(y_{i}-\bar{y}\right)
\end{gathered}
$$

where $C_{x y}$ is the cross-covariance; $r_{x y}(k)$ is cross-correlation coefficient; $k$ is time lag; $x_{i}$ and $y_{i}$ are time series; $N$ is number of data and $m\left(r(k)=\left(r_{0}, \ldots, r_{k}, \ldots, r_{m}\right)\right)$ is the number of cross-correlation coefficients.

Cross-correlation is the correlation between two time series that are shifted in time relative to one another. Reaction delay is a characteristic of many natural physical phenomena, especially geophysical ones. The cross-correlation function of two time series gives the cross-correlation coefficient as a function of time lag. In a single time step, the cross-correlation function can be viewed as the correlation coefficient of two time series, one of which is displaced by a certain number of time units. It is important that the time series measurements are consistent with each other, so measurements should be performed at the same time (on the same day if the measurement frequency is one day or at the same hour if the measurement frequency is one hour). 
Cross-correlation analysis is performed by calculating the cross-correlation coefficient for each time step. The coefficients are plotted on the correlogram or cross-correlogram. The correlogram is plotted so that in the coordinate system the time steps are plotted on the $\mathrm{x}$ axis and the correlation coefficients on the $\mathrm{y}$ axis. On the correlogram we can see for which time step we obtained the highest cross-correlation coefficient and its value. The time step with the highest crosscorrelation coefficient is the reaction delay time when the time series are maximally aligned. In case of replacing the order of the time series, the same correlogram will be obtained, only of the opposite sign. Cross-correlation analysis was usually performed in karstic catchment (Fronzi et al., 2020; Buljan et al., 2019; Pavlić and Parlov, 2019).

\subsection{Flow duration curve analysis}

The flow duration curve (FDC) shows the dependence of the magnitude and frequency of daily, monthly or annual flows on a watercourse, and thus shows a percentage of the duration of a flow equal to or greater than that flow (Vogel and Fennessey, 1994).

To construct a flow duration curve, one starts from the cumulative frequency of a flow variable. It represents the sum of the frequencies of all values less than or equal to that value, or vice versa. Cumulative frequency represents durability and is plotted with a duration curve. The flow duration curve, together with the hyetograph, water level diagram, hydrograph, water level duration curve and water level and flow frequency curves, belongs to the basic graphical representations in hydrology (Žugaj et al., 2011; Pavlić and Jakobović, 2018).

\section{Research area and data used}

The study area is located within the Varaždin aquifer system in NW Croatia (Fig. 1). The Varaždin aquifer is unconfined and composed of Quaternary alluvial sediments deposited during the Pleistocene and Holocene (Prelogović and Velić, 1988). The aquifer system consist of three layers: upper aquifer, semipermeable interlayer, and lower aquifer (Karlović et al., 2021). The aquifer material is mainly composed of gravel and sand with variable portions of silt and clay. The thickness of the aquifer varies from around $5 \mathrm{~m}$ in the northwestern part to over $100 \mathrm{~m}$ in the eastern part of the study area at the Bartolovec pumping site (Fig. 2, cross-section 1-1'). The covering layer of the aquifer is not continuous and there is a high risk of contamination from the surface. There are two active pumping sites in the study area - Vinokovšcak and Bartolovec, and one inactive pumping site - Varaždin. Groundwater generally flows from northwest to the southeast and is connected with the surface water: accumulation lake Varaždin, Drava River, and Plitvica stream.

Plitvica stream (Fig. 3) springs on Ravna Gora and represents the westernmost tributary of the Drava River in Croatia. It is $70 \mathrm{~km}$ long and its mouth is 
in Ludbreg Podravina near Veliki Bukovac. It has low banks and a rainy regime, so it often flooded the surrounding area at higher water levels. After regulation in the Varaždin field, flood hazards were eliminated, which enabled the conversion of underwater meadows into arable land (Larva, 2008).

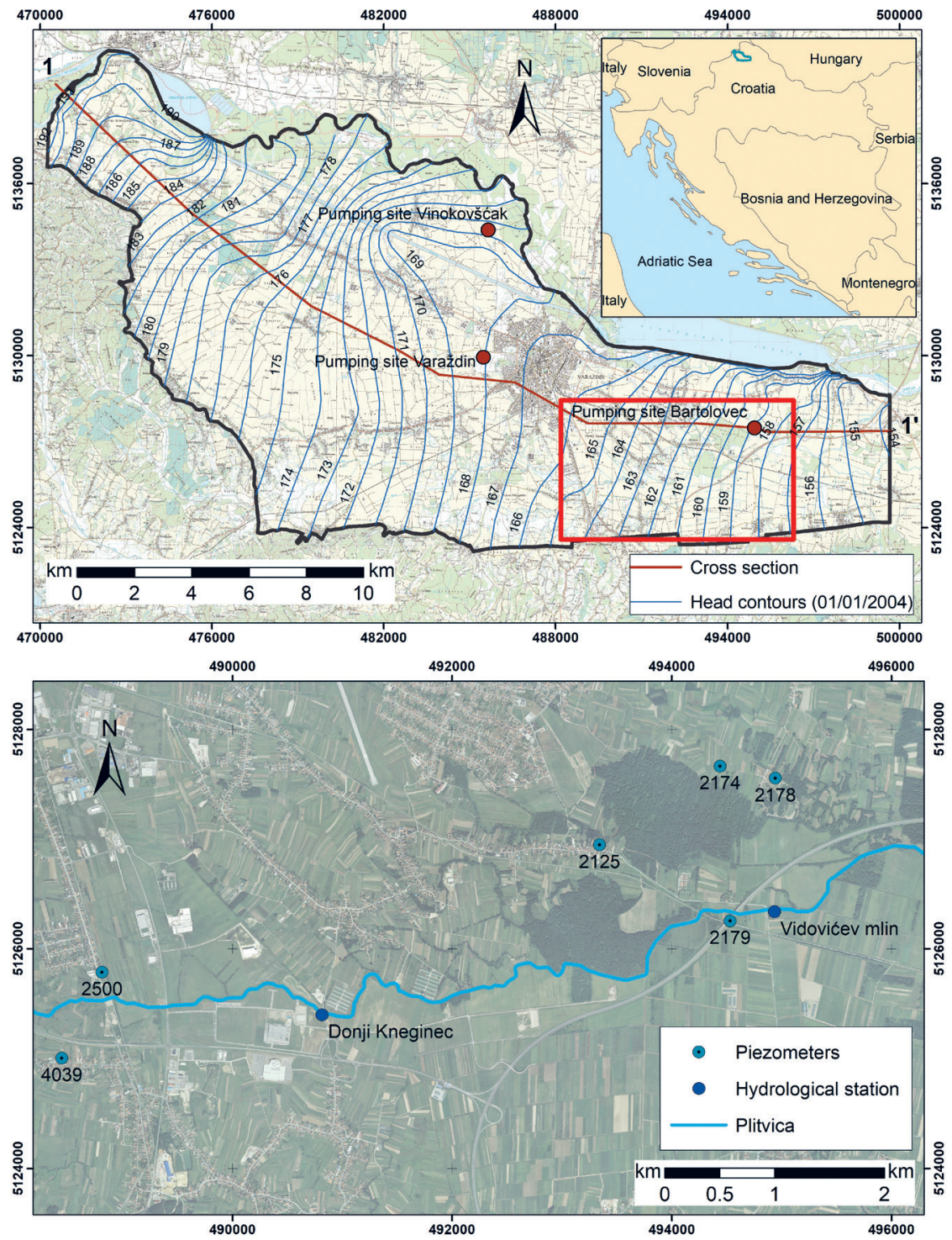

Figure 1. Geographical position of the study area with locations of the analysed piezometers and hydrological stations of the Plitvica stream; the transect 1-1' corresponds to the representative hydrogeological cross-section shown in Fig. 2. 
For the purposes of this paper and the analysis of the interaction of Plitvica stream water levels, groundwater levels and precipitation, data from the Croatian Meteorological and Hydrological Service (DHMZ) were used (Tab. 1). Data on the Plitvica water levels were processed for two hydrological stations: Kneginec Donji and Vidovićev Mlin. Groundwater levels data were taken for piezometers located in the narrow inflow area of hydrological stations. Six piezometers were considered in total: 2500, 4039, 2174, 2178, 2179 and 2125 (Fig. 1).

Plitvica water levels are measured on a daily basis, while groundwater levels are measured every 3 to 4 days. In order to reduce the data to the same time series, the piezometer levels were interpolated by the linear interpolation method in MS Excel, yielding daily measurements. Linear interpolation of groundwater levels to obtain daily measurements was necessary in order to perform statistical correlation and cross-correlation methods. Precipitation data were used with five meteorological stations located in the wider inflow area of piezometers and Plitvica stream: Donji Macelj, Klenovnik, Križovljan Grad, Šemovec and Varaždinske Toplice. The analysed period covered the period from January $1^{\text {st }}$ 2016 to December $28^{\text {th }} 2017$, that is, two years.

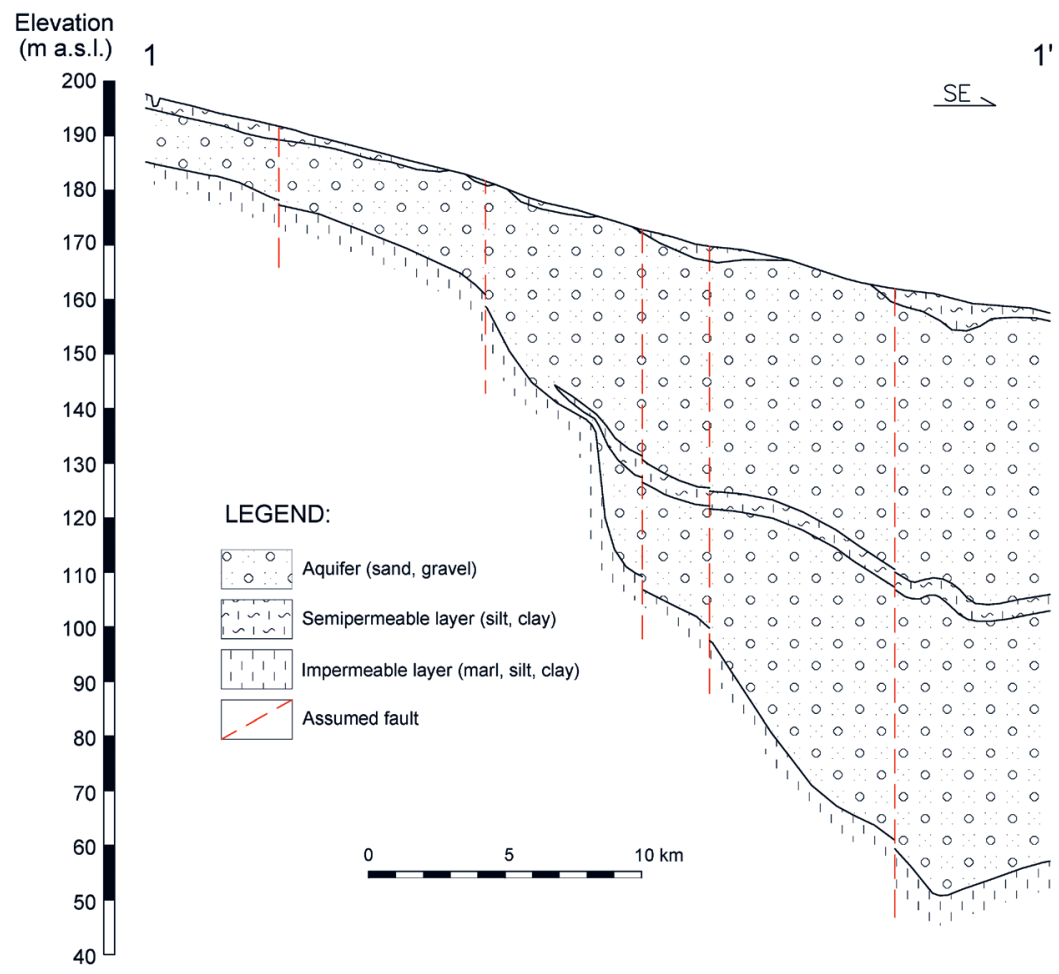

Figure 2. Schematic hydrogeological cross-section across the Varaždin aquifer (modified according to Larva, 2008). 

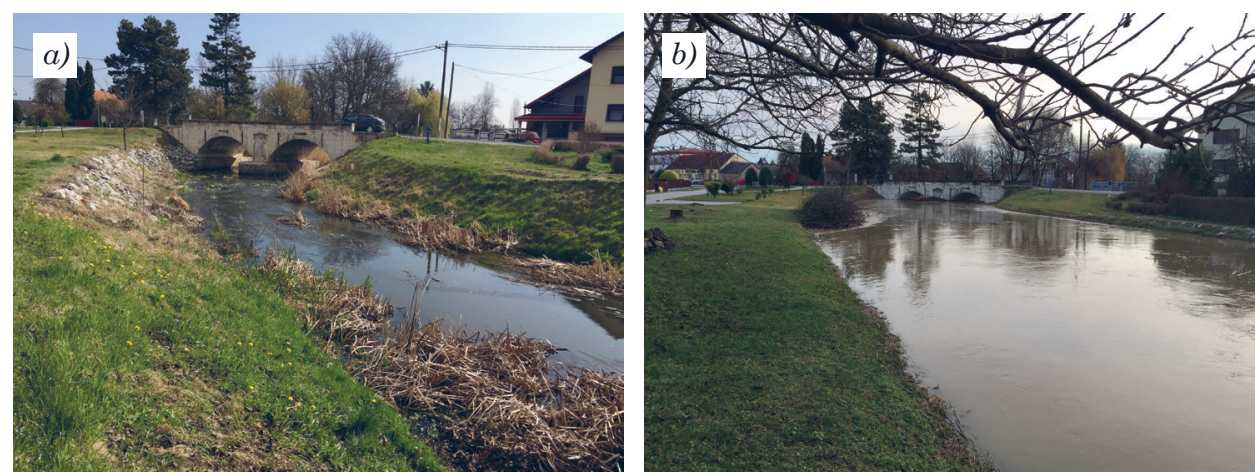

Figure 3. Plitvica stream (near Jalkovec village) during dry (a) and rainy season (b).

Table 1. Measuring stations data.

\begin{tabular}{cccc}
\hline \multirow{2}{*}{ Station name } & Type & \multicolumn{2}{c}{ Coordinates (HTRS96/TM) } \\
& & E & N \\
\hline 2500 & MW & 488812 & 5125787 \\
2174 & MW & 488445 & 5125004 \\
2178 & MW & 494441 & 5127664 \\
2179 & MW & 494943 & 5127555 \\
2125 & MW & 494531 & 5126255 \\
Kneginec Donji & MW & 493344 & 5126947 \\
Vidovićev mlin & HYD & 490816 & 5125399 \\
Šemovec & HYD & 494935 & 5126337 \\
Donji Macelj & MET & 497427 & 5128920 \\
Klenovnik & MET & 448547 & 5118021 \\
Križovljan Grad & MET & 466592 & 5125298 \\
Varaždinske Toplice & MET & 470514 & 5138249 \\
\hline
\end{tabular}

Type: HYD - hydrological station; MET - meteorological station; MW - monitoring well

\section{Results and discussion}

Figures 4 to 9 show the oscillation of groundwater levels in time, which are compared with Plitvica stream water levels and precipitation during the study period.

The graphs show that the groundwater level in the surrounding piezometers is higher than the Plitvica level most of the time. The exception is piezometer 2178 (Fig. 8), which shows the constant overlap of water levels and groundwater levels in the piezometer due to possible impact of Bartolovec pumping site. Also, piezometer 2179 (Fig. 9) shows sporadic overlap of water levels and groundwater 


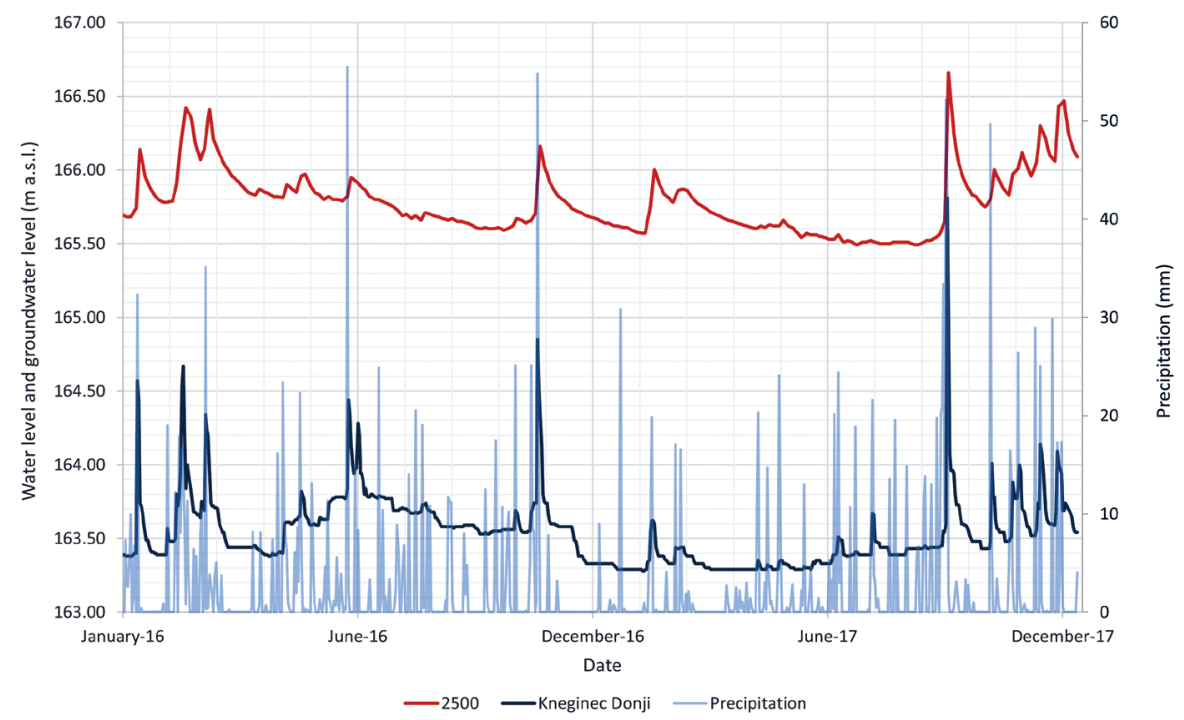

Figure 4. Pluviograph obtained from mean precipitation from meteorological stations compared to the level of the Kneginec Donji hydrological station and piezometer 2500.

levels. It can be said that there is a certain regularity between water levels, groundwater levels and rainfall, that is, the increase or decrease of one variable is accompanied by the other two. Based on the graphs.

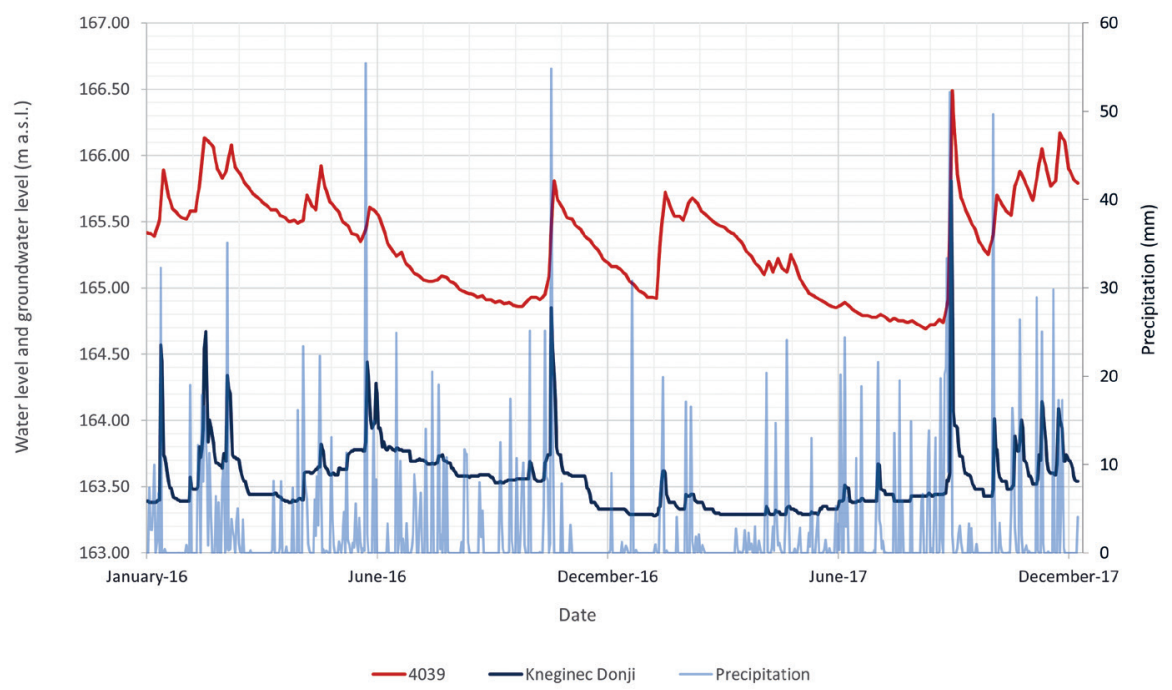

Figure 5. Pluviograph obtained from mean precipitation from meteorological stations compared to the level of the Kneginec Donji hydrological station and piezometer 4039. 


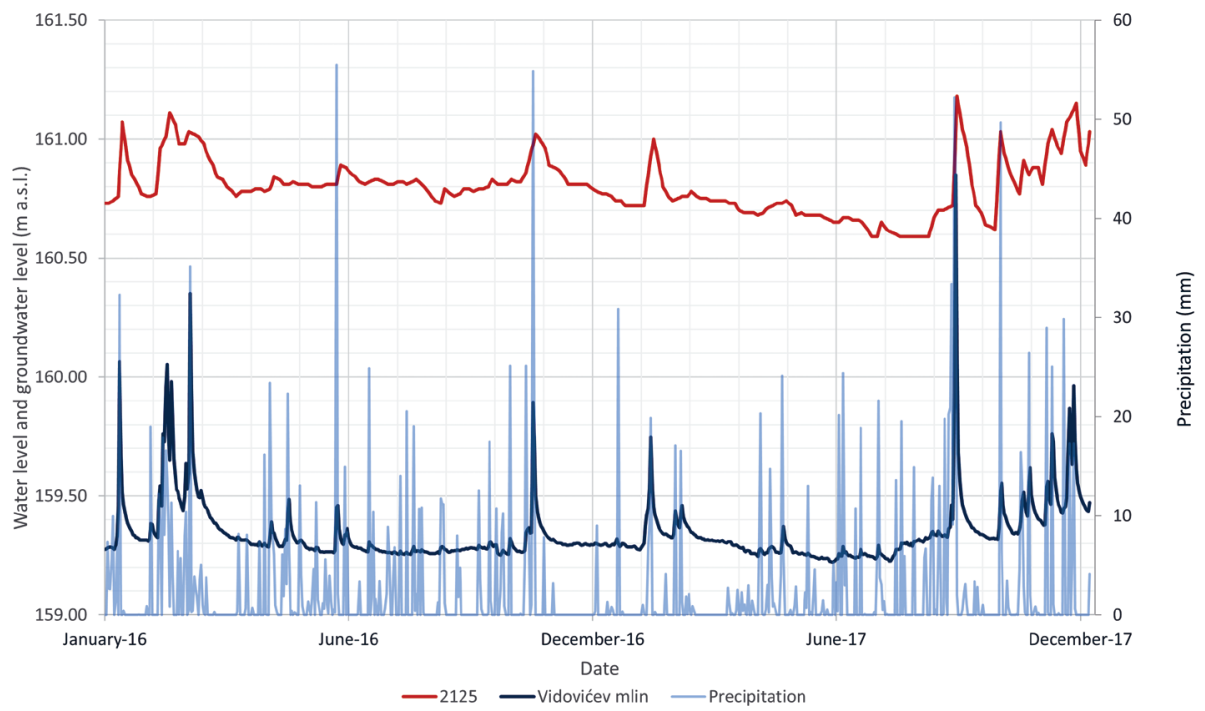

Figure 6. Pluviograph obtained from mean precipitation from meteorological stations compared to the level of the Vidovićev mlin hydrological station and piezometer 2125.

Correlation analysis was performed to determine the strength of the hydra it can be concluded that Plitvica is draining the aquifer, which will be endeavoured to confirm by duration curves for hydrological station Vidovićev mlin.

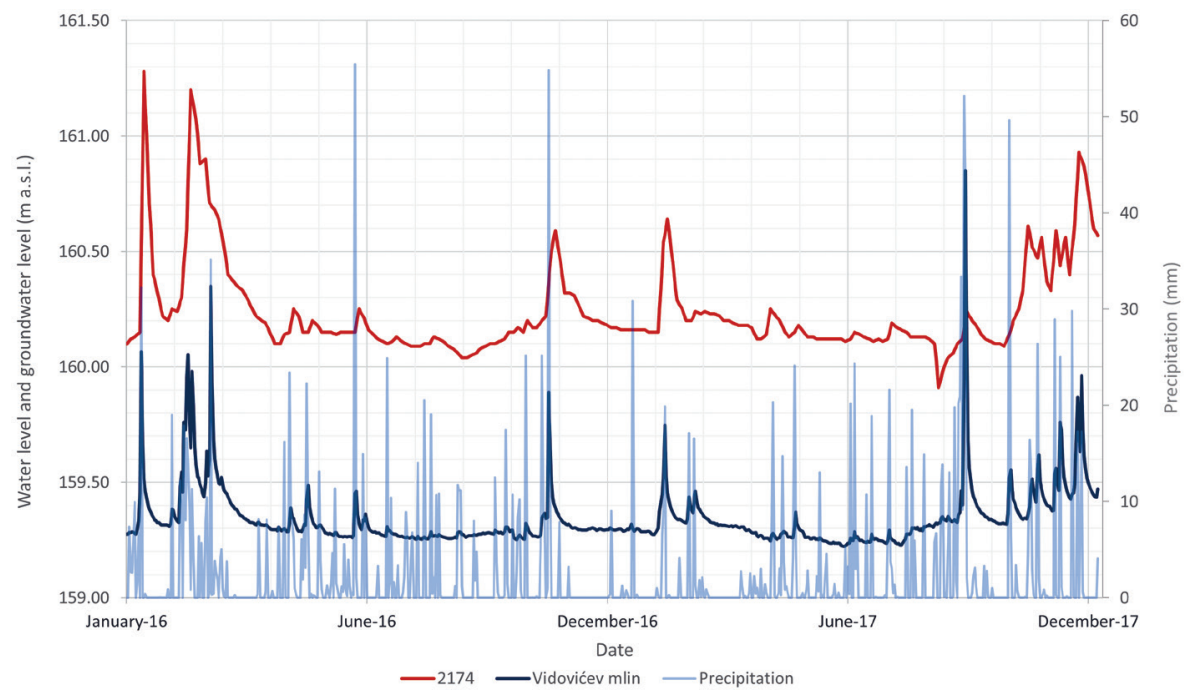

Figure 7. Pluviograph obtained from mean precipitation from meteorological stations compared to the level of the Vidovićev mlin hydrological station and piezometer 2174. 


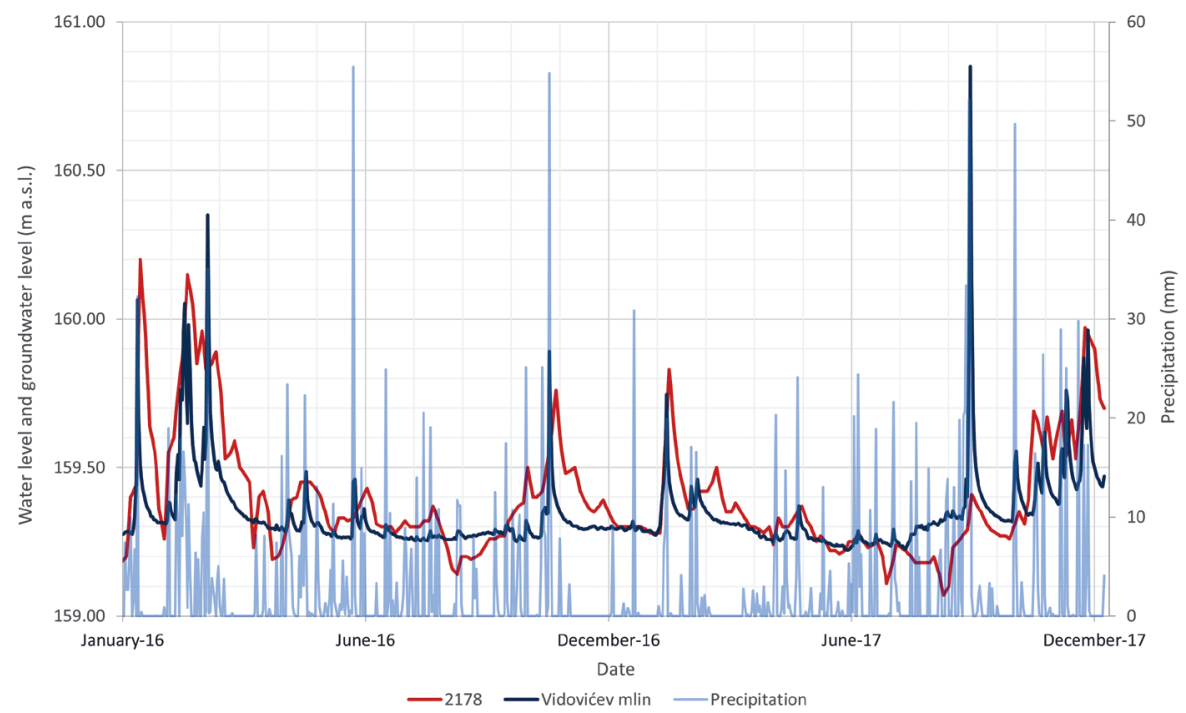

Figure 8. Pluviograph obtained from mean precipitation from meteorological stations compared to the level of the Vidovićev mlin hydrological station and piezometer 2178.

Correlation analysis was performed to determine the strength of the hydraulic connection between the Plitvica water levels and groundwater levels. The results of the analysis are presented in Tab. 2, which shows the examined rela-

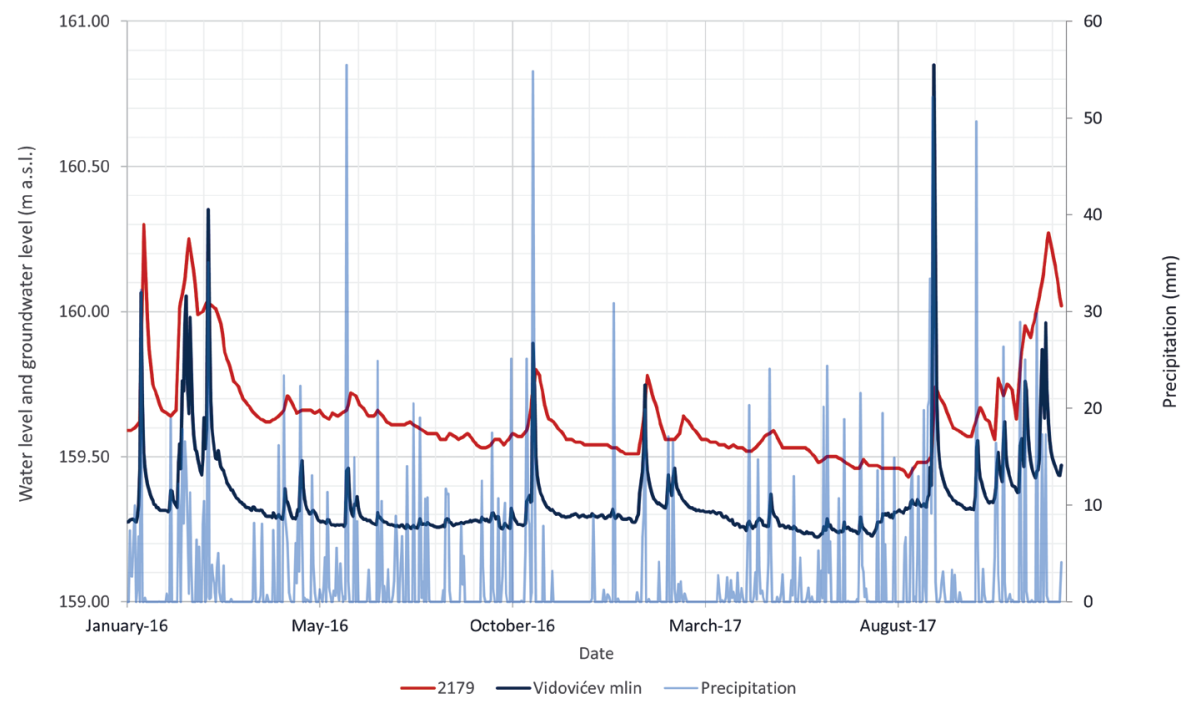

Figure 9. Pluviograph obtained from mean precipitation from meteorological stations compared to the level of the Vidovićev mlin hydrological station and piezometer 2179. 
Table 2. Results of data processing by correlation method.

\begin{tabular}{ccc}
\hline The analysed pair & $r$ & $\begin{array}{c}\text { Correlation level } \\
\text { (Petz, 2004) }\end{array}$ \\
\hline 2500/Kneginec Donji & 0.61 & significant \\
4039/Kneginec Donji & 0.44 & significant \\
2125/Vidovićev mlin & 0.66 & significant \\
2174/Vidovićev mlin & 0.64 & significant \\
2178/Vidovićev mlin & 0.64 & significant \\
2179/Vidovićev mlin & 0.67 & significant \\
\hline
\end{tabular}

tionships (correlated pairs), obtained correlation coefficients $r$ and a description of the level of correlation - the correlation coefficient according to (Petz, 2004). Although all values of the correlation coefficient $r$ have relatively high values and, according to (Petz, 2004), have a significant descriptive value, such an analysis is by no means sufficient to fully describe such interactions.

Autocorrelation was performed for all piezometers and for both hydrological stations in Plitvica. The results of autocorrelation, auto correlograms are shown in Fig. 10. In all auto-correlograms, the coefficient of autocorrelation is 1 for time lag 0 which means that the time series are auto-correlated with themselves.

The auto-correlograms observed the time (number of days) required for the auto-correlation coefficient to fall below 0.2 , indicating the memory effect, that is, the duration of the system response to the input pulse (Mangin, 1984). The temporal results related to the memory effect are shown in Tab. 3.

The analysis of auto-correlograms for groundwater and surface water levels shows that the correlation coefficient value drops below 0.2 after a long period of time, for groundwater in the range of 45 to 62 days, and for surface water in the range of 24 to 39 days. The results obtained indicate a long-term memory of the system in which the system permanently affects itself. This can be explained

Table 3. Memory effect duration values at piezometer and hydrological stations.

\begin{tabular}{cc}
\hline Station & $\begin{array}{c}\text { Memory-effect } \\
\text { (days) }\end{array}$ \\
\hline 2125 & 55 \\
2174 & 45 \\
2178 & 46 \\
2179 & 54 \\
2500 & 60 \\
4039 & 62 \\
Kneginec Donji & 39 \\
Vidovićev mlin & 24 \\
\hline
\end{tabular}



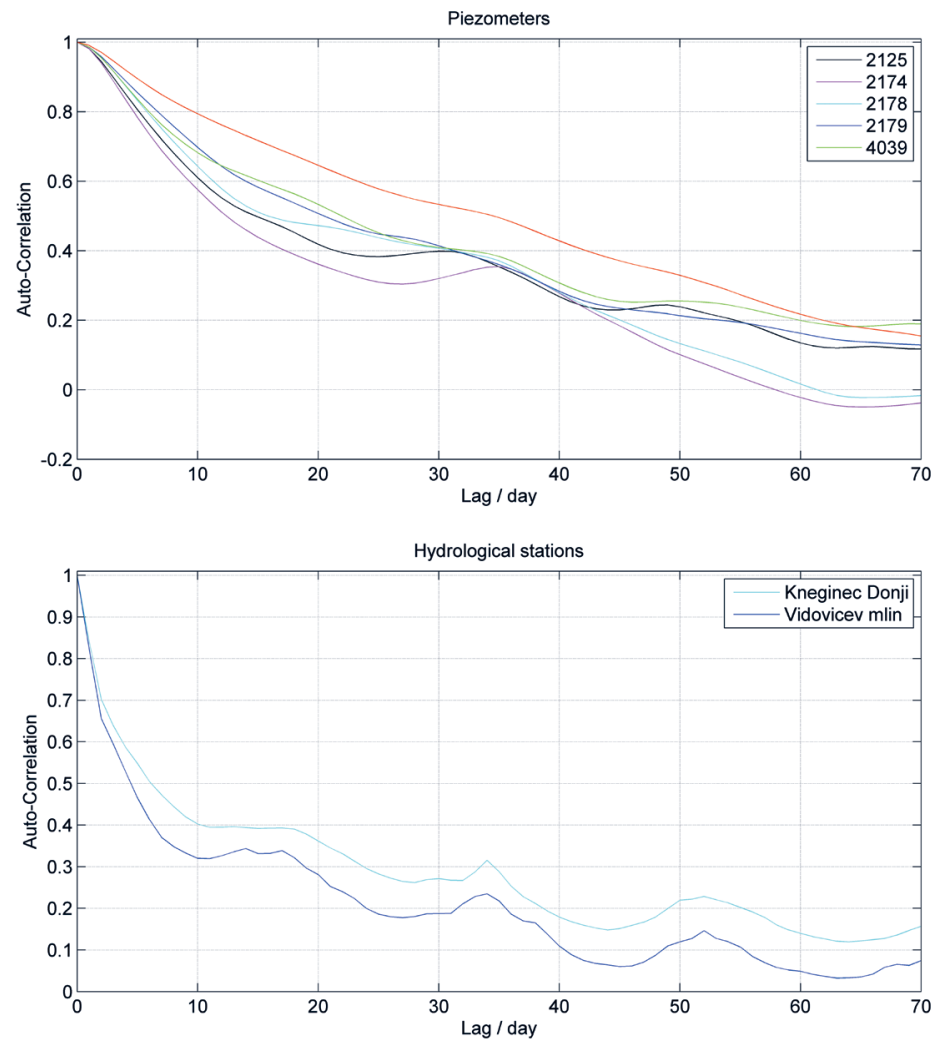

Figure 10. Auto-correlation functions (ACF) for time series on piezometers and hydrological stations.

Table 4. Results of data processing by cross-correlation method.

\begin{tabular}{llc}
\hline The analysed pair & \multicolumn{1}{c}{$r$} & Lag (days) \\
\hline 2125 / Vidovićev mlin & 0.7258 & 2 \\
2174 / Vidovićev mlin & 0.7083 & 2 \\
2178 / Vidovićev mlin & 0.7018 & 2 \\
2179 / Vidovićev mlin & 0.7336 & 2 \\
2500 / Kneginec Donji & 0.6319 & 1 \\
4039 / Kneginec Donji & 0.4426 & 1 \\
2125 / Precipitation & 0.2488 & 4 \\
2174 / Precipitation & 0.1536 & 5 \\
2178 / Precipitation & 0.1568 & 5 \\
2179 / Precipitation & 0.17 & 5 \\
2500 / Precipitation & 0.2431 & 5 \\
4039 / Precipitation & 0.1687 & 4 \\
Precipitation / Vidovićev mlin & 0.4206 & 0 \\
Precipitation / Kneginec Donji & 0.417 & 1 \\
\hline
\end{tabular}



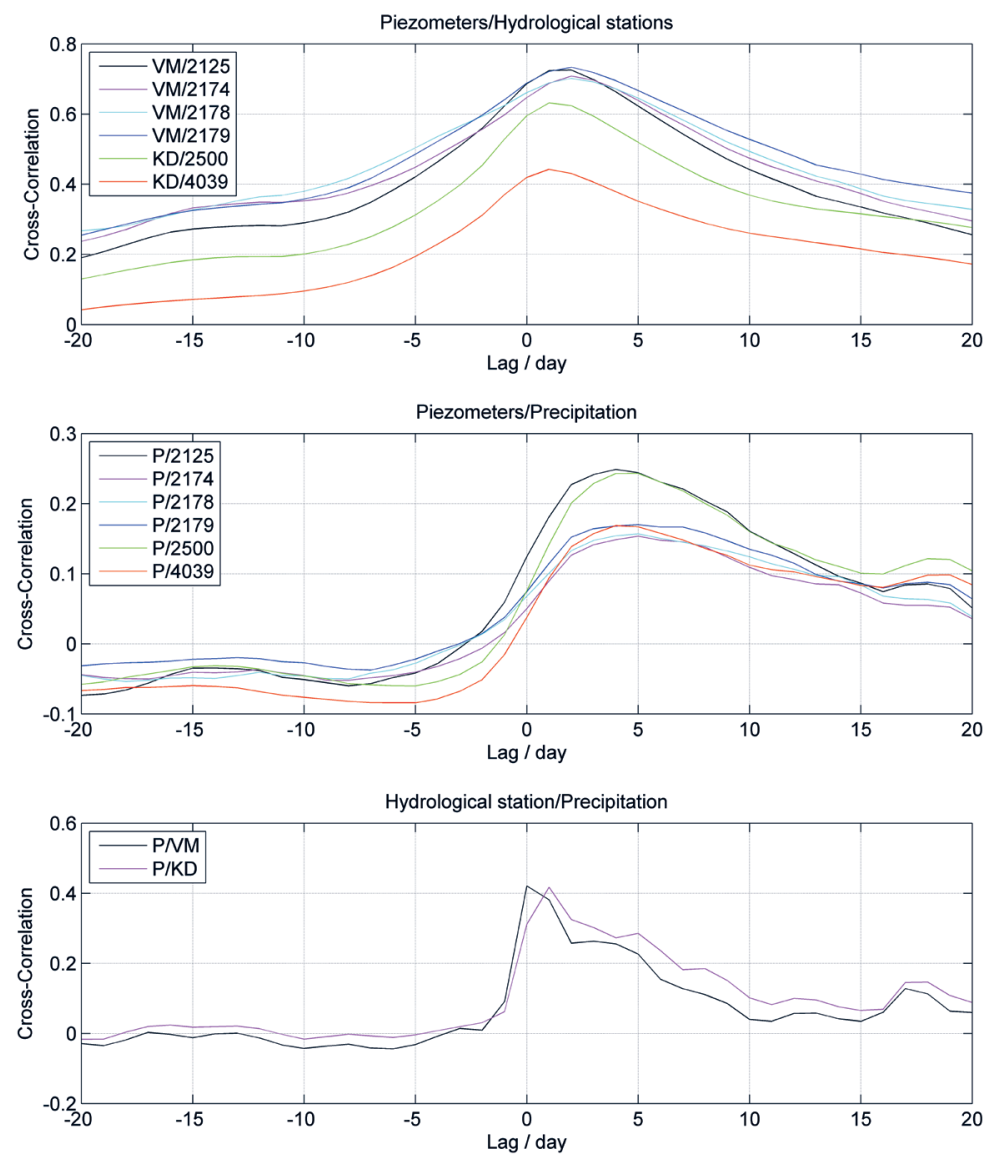

Figure 11. Cross-correlation functions (CCF) of daily measurements of groundwater levels, Plitvica water levels and precipitation.

by the slow flow, and thus by the slow transmission of pressure signals, which makes it almost impossible for the system to lose memory.

The cross-correlation function compared the time series of Plitvica water levels and groundwater levels (Fig. 11 above), precipitation and groundwater levels (Fig. 11 middle) and precipitation and Plitvica water levels (Fig. 11 below). Cross-correlation analysis determines the time lag expressed in days between the observed variables for the maximum cross-correlation coefficient. A summary of the results is shown in Tab. 4.

The cross-correlation functions of the time series of the Plitvica water levels and the groundwater levels showed a time lag of the rise in groundwater levels in piezometers relative to the Plitvica water levels, that is, a pressure transfer 
time of two days for the hydrological station Vidovićev mlin and one day for the hydrological station Kneginec Donji. The maximum correlation coefficients are shown in Tab. 4, ranging from 0.4426 to 0.6319 for the Kneginec Donji station and 0.7018 to 0.7336 for the Vidovićev mlin.

Cross-correlation functions of mean precipitation time series and groundwater levels showed a time lag of groundwater levels in piezometers relative to the mean precipitation in the study area, that is, a pressure transfer time of $4-5$ days. The maximum correlation coefficients are very low, ranging from 0.1536 to 0.2488 (Tab. 4).

Cross-correlation functions of time series of mean precipitation and water levels of Plitvica showed a time lag of the increase of the water levels of Plitvica in relation to the mean values of precipitation in the study area, that is, the time of pressure transfer from zero (Vidovićev mlin) to one day (Kneginec Donji). The maximum correlation coefficients are higher than in groundwater, amounting to 0.417 for the Kneginec Donji station and 0.4206 for the Vidovićev mlin.

Figures 8 and 9 show that the water levels of the Vidovicev mlin and piezometers 2178 and 2179 vary around similar water levels, Figs. 12 and 13 show a comparison of the Plitvica water level duration curves at the Vidovicev mlin and the nearby piezometers (2178 and 2179).

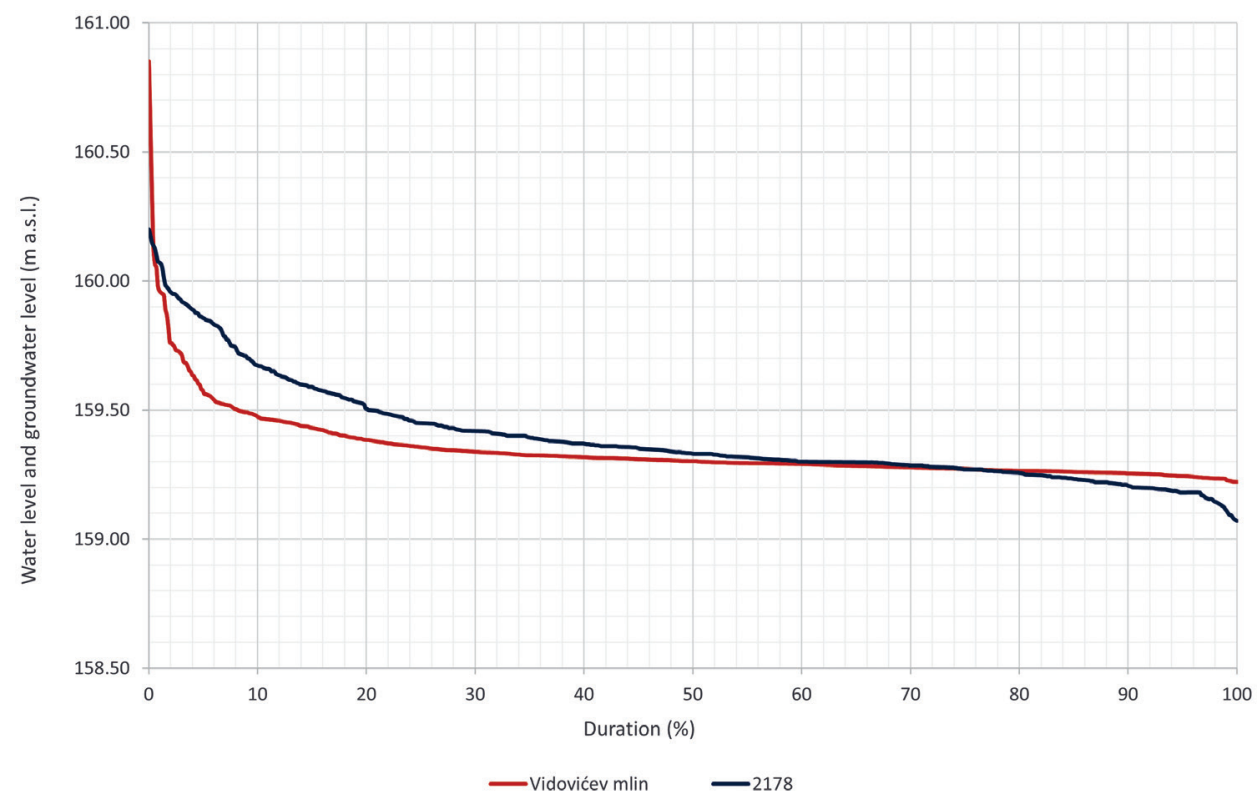

Figure 12. Duration curves of groundwater levels in piezometer 2178 and water levels at the hydrological station Vidovićev mlin. 


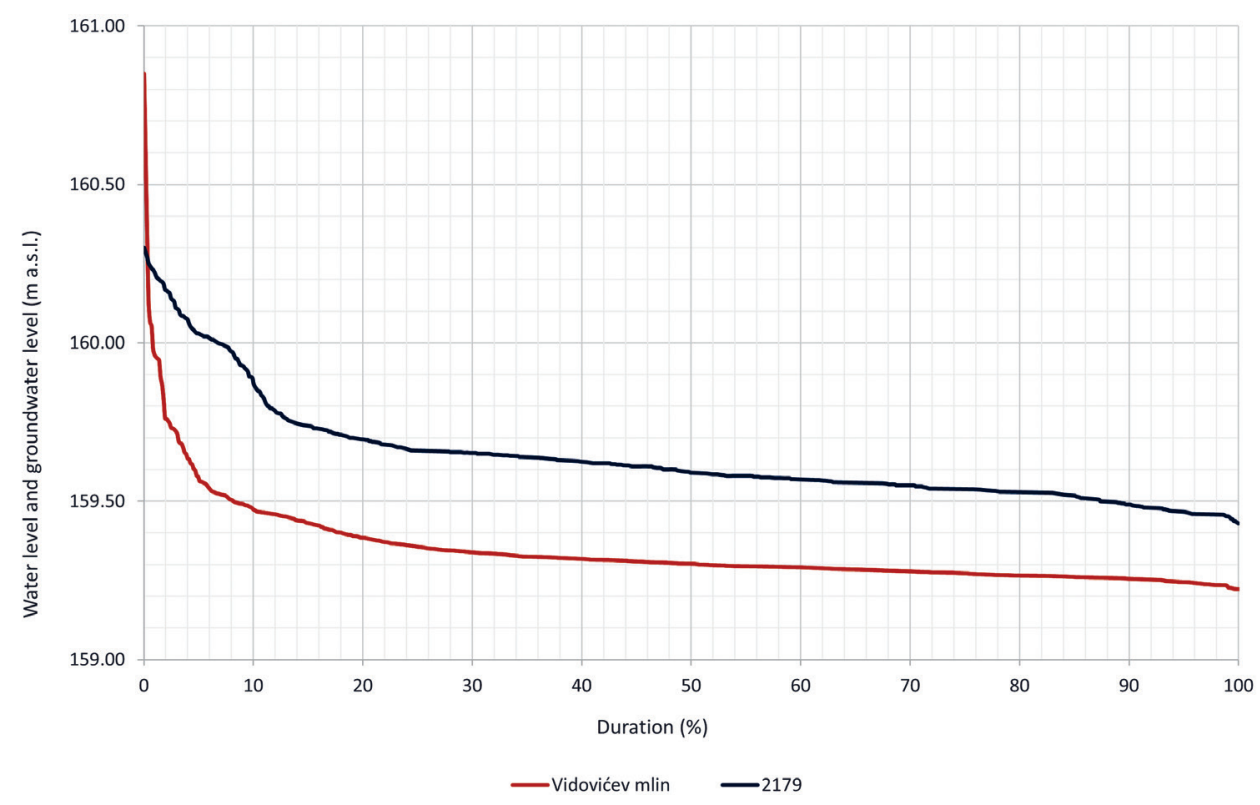

Figure 13. Duration curves of groundwater levels in piezometer 2179 and water levels at the hydrological station Vidovićev mlin.

The water level of Plitvica is $25.8 \%$ of the time higher and $74.2 \%$ of the time lower than the groundwater level in piezometer 2178. Plitvica predominantly drains this part of the aquifer.

The water level of Plitvica is $0.3 \%$ of the time higher and $99.7 \%$ of the time lower than the groundwater level in the piezometer 2179. Plitvica predominantly drains this part of the aquifer. Analyses of the duration curves confirmed that Plitvica almost completely drains groundwater, except in the vicinity of the piezometer 2178 where Plitvica recharges the aquifer about a quarter of the time.

Figure 14 shows that the water level of Plitvica is lower than the groundwater level, which means that Plitvica drains groundwater. According to the results of the analyses, there is a certain underground hydraulic connection between the Plitvica stream and the piezometers. The connection is defined with a time lag of 1-2 days, that is, the amount of pressure transfer time between Plitvica and the piezometer. For precipitation and groundwater levels, this relationship is much weaker, with a lag time of $4-5$ days with a weak cross-correlation coefficient. The least time lag, within a day, was established between precipitation and Plitvica stream. The results obtained seem logical, precipitation will have a much faster effect on surface water levels as precipitation directly flows into the surface recipient, while piezometers will respond much more slowly and less 


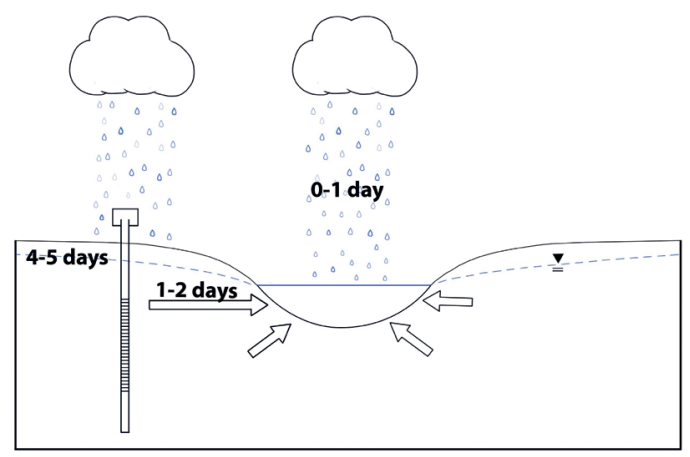

Figure 14. Established links between groundwater levels, Plitvica water levels and precipitation in the study area.

directly to precipitation. The groundwater link between Plitvica stream and piezometers has a much greater and faster impact with each other, than the link between precipitation and groundwater.

\section{Conclusion}

Within the framework of this paper, the hydraulic connection between the Plitvica stream and the surrounding piezometers that capture the groundwater of the Varaždin alluvial aquifer is made, using statistical methods and flow duration curves. Rainfall quantities over a wider study area were also considered to examine the effect of precipitation on Plitvica water levels and groundwater levels in surrounding piezometers. The following statistical methods were used: correlation method, cross-correlation method and auto-correlation method. Time series of data on water levels and groundwater levels in piezometers for the period from January $1^{\text {st }}, 2016$ to December $28^{\text {th }}, 2017$ were processed.

Correlation analysis was performed to determine the strength of the hydraulic connection between the Plitvica water level and groundwater piezometers. The results of the analysis show that there is generally a significant correlation between the Plitvica water levels and the surrounding piezometers that capture groundwater. The direction of the correlation is positive, which means that the increase or decrease in the groundwater level in the piezometers is accompanied by an increase or decrease in the water level of Plitvica.

Auto-correlation analyses were made for Plitvica and groundwater in order to determine the memory effect of the system. The results obtained show that the auto-correlation coefficient drops below 0.2 after a longer period. Long-term system memory can be explained by slow flow and thus slow pressure transfer.

Cross-correlation analysis compared the time series of Plitvica water levels and groundwater levels, precipitation and groundwater levels, and Plitvica water levels and precipitation. Time lags in days between observed variables for 
maximum cross-correlation coefficient were determined. Cross-correlation analyses of the time series of the Plitvica water levels and groundwater levels showed a time lag of the reaction of the rise of groundwater levels in piezometers relative to the Plitvica water level, that is, the time of pressure transfer from one to two days with a fairly significant cross-correlation coefficient. The results obtained are very unusual because such a rapid pressure transfer is characteristic of large gravels where a very strong hydraulic connection is present. The expected time lag before the cross-correlation analysis was performed, was by an order of magnitude greater than the obtained values, based on the relatively large distance of piezometers from hydrological stations (from 0.4 to $2.4 \mathrm{~km}$ ) and assuming that Plitvica was collimated at the bottom, i.e. that the bottom of the bed is covered with sediment and sludge deposited due to less water flow.

Analyses of the flow duration curves revealed that Plitvica almost completely drains groundwater, except in the vicinity of the piezometer 2178 where Plitvica recharges the aquifer about a quarter of the time, which is also evident from the graphs of the comparison of water levels and groundwater levels.

Obviously, there is a possibility that communication between Plitvica and groundwater occurs through the banks of Plitvica, that is, the muddy bottom does not represent a crucial factor in establishing a hydraulic connection. If there were more piezometers on the left and right side of Plitvica, then it might be somewhat more succinct to conclude, but as there is not too much information available, these results should be taken with caution.

Acknowledgements - This research was financially supported by the Croatian Scientific Foundation (HRZZ) under grant number HRZZ-IP-2016-06-5365 and supported by Young Researchers Career Development Project - Training of New PhDs - HRZZ \& ESF. The authors would like to thank the Croatian Meteorological and Hydrological Service for providing hydrological data for the hydrological stations Kneginec Donji and Vidovićev mlin and meteorological data for meteorological stations Donji Macelj, Klenovnik, Križovljan Grad, Šemovec and Varaždinske Toplice.

\section{References}

Box, G. E. P., Jenkins, G. M. and Reinsel, G. C. (2008): Time series analysis: Forecasting and control. John Wiley \& Sons, Ltd., Hoboken, N. J., 746 pp.

Buljan, R., Pavlić, K., Terzić, J. and Perković, D. (2019): A conceptual model of groundwater dynamics in the catchment area of the Zagorska Mrežnica spring, the karst massif of Kapela Mountain. Water, 11(10), 1983, https://doi.org/10.3390/w11101983.

Chiaudani, A., Di Curzio, D., Palmucci, W., Pasculli, A., Polemio, M. and Rusi, S. (2017): Statistical and fractal approaches on long time-series to surface-water/groundwater relationship assessment: A Central Italy alluvial plain case study, Water, 9(11), 850, https://doi.org/10.3390/w9110850.

Coluccio, K., and Morgan, L. K. (2019): A review of methods for measuring groundwater-surface water exchange in braided rivers, Hydrol. Earth Syst. Sci., 23, 4397-4417, https://doi.org/10.5194/ hess-23-4397-2019.

Davis, J. C. (2002): Statistics and data analysis in geology, $3^{\text {rd }}$ Edition. John Wiley \& Sons, Ltd., New York, $656 \mathrm{pp}$. 
Fronzi, D., Di Curzio, D., Rusi, S., Valigi, D. and Tazioli, A. (2020): Comparison between periodic tracer tests and time-series analysis to assess mid- and long-term recharge model changes due to multiple strong seismic events in carbonate aquifers, Water, 12(11), 3073, https://doi. org/10.3390/w12113073.

Kapuralić, J., Posavec, K., Kurevija, T. and Macenić, M. (2018): Identification of the Sava River temperature influence on the groundwater temperature of the Zagreb and Samobor-Zaprešic aquifers as a part of shallow geothermal potential, Rud.-geol.-naft. zb., 33(5), 59-69, https://doi. org/10.17794/rgn.2018.5.6.

Karlović, I., Marković, T., Vujnović, T. and Larva, O. (2021): Development of a hydrogeological conceptual model of the Varaždin alluvial aquifer, Hydrology, 8(1), 19, https://doi.org/10.3390/ hydrology8010019.

Larva, O. (2008): Aquifer vulnerability at catchment area of Varaždin pumping sites. $\mathrm{PhD}$ Thesis, Faculty of Mining, Geology and Petroleum Engineering, University of Zagreb, Zagreb, 198 pp (in Croatian with English abstract).

Li, M., Liang, X., Xiao, C. and Cao, Y. (2020): Quantitative evaluation of groundwater-surface water interactions: Application of cumulative exchange fluxes method, Water, 12(1), 259, https://doi. org/10.3390/w12010259.

Li, P., Wu, J. and Qian, H. (2016): Preliminary assessment of hydraulic connectivity between river water and shallow groundwater and estimation of their transfer rate during dry season in the Shidi River, China, Environ. Earth Sci., 75(2), 1-16, https://doi.org/10.1007/s12665-015-4949-7.

Mangin, A. (1984): Pour une meilleure connaissance des systèmes hydrologiques à partir des analyses corrélatoire et spectrale, J. Hydrol., 67, 25-43, https://doi.org/10.1016/0022-1694(84)90230-0.

Marković, T., Karlović, I., Perčec Tadić, M. and Larva, O. (2020): Application of stable water isotopes to improve conceptual model of alluvial aquifer in the Varaždin area, Water, 12(2), 379, https:// doi.org/10.3390/w12020379.

MATLAB (2010): Version 7.11.0.584 (R2010b). The MathWorks Inc., Natick, Massachusetts.

Microsoft Corporation (2019): Microsoft Excel. https://office.microsoft.com/excel.

Pavlić, K. and Jakobović, D. (2018): High flows from Gornja Dobra basin, Rud.-geol.-naft. zb., 33(3), 45-52, https://doi.org/10.17794/RGN.2018.3.5.

Pavlić, K. and Parlov, J. (2019): Cross-correlation and cross-spectral analysis of the hydrographs in the northern part of the Dinaric karst of Croatia, Geosciences, 9(2), 86, https://doi.org/10.3390/ geosciences9020086.

Petz, B. (2004): Basis statistics methods for nonmathematicians. Naklada Slap, Jastrebarsko, Croatia, $384 \mathrm{pp}$ (in Croatian).

Posavec, K. and Škudar, S. (2016): Correlation, regression and cross-correlation modelling of time series in hydrogeology, in: Matematičke metode $i$ nazivlje u geologiji, edited by Malvić, T. and Velić, J. 75-90, Zagreb.

Posavec, K., Vukojević, P., Ratkaj, M. and Bedeniković, T. (2017): Cross-correlation modelling of surface water - Groundwater interaction using the Excel spreadsheet application, Rud.-geol.-naft. $z b ., 32(35)$, 25-32, https://doi.org/10.17794/rgn.2017.1.4.

Prelogović, E. and Velić, I. (1988): Kvartarna tektonska aktivnost u zapadnom dijelu Dravske Potoline, Geol. Vjesnik, 41, 237-253 (in Croatian).

Taylor, J. R. (1997): An introduction to error analysis: The study of uncertainties in physical measurements. $2^{\text {nd }}$ Edition, University Science Books, Sausalito, California, 327 pp.

Vogel, R. M. and Fennessey, N. M. (1994): Flow-duration curves. I: New interpretation and confidence intervals, J. Water Resour. Plan. Manag., 120, 485-504, https://doi.org/10.1061/(ASCE)07339496(1994)120:4(485).

Žugaj, R., Andreić, Ž., Pavlić, K. and Fuštar, L. (2011): Flow duration curves. Građevinar, 63, 10611068. 


\title{
SAŽETAK
}

\section{Analiza hidrauličke veze potoka Plitvice i podzemnih voda varaždinskog aluvijalnog vodonosnika}

\author{
Igor Karlović, Krešimir Pavlić, Kristijan Posavec i Tamara Marković
}

Kombinacija različitih statističkih metoda i krivulja trajanja korištena je za ispitivanje hidrauličke veze potoka Plitvice i okolnih piezometra koji zahvaćaju podzemne vode varaždinskog aluvijalnog vodonosnika. Također, razmatrane su količine oborina sa šireg područja istraživanja kako bi se utvrdio utjecaj oborina na vodostaj Plitvice i razine podzemne vode. U radu su korištene sljedeće statističke metode: korelacija, auto-korelacija i kros-korelacija. Korelacijske analize pokazuju da generalno postoji značajna povezanost između vodostaja Plitvice i razina podzemnih voda, s pozitivnim smjerom korelacije. Analiza auto-korelograma za podzemne i površinske vode pokazuje da vrijednost koeficijenta korelacije pada ispod 0,2 nakon duljeg vremenskog razdoblja, što ukazuje na dugotrajnu memoriju sustava koja se može objasniti sporim tečenjem, odnosno sporim prijenosom tlaka. Kros-korelacijska analiza vremenskih nizova između vodostaja Plitvice i podzemnih voda pokazala je vremensko zaostajanje od 1-2 dana s prilično značajnim koeficijentom korelacije. Između oborina i podzemnih voda veza je mnogo slabija, s vremenskim zaostajanjem od 4-5 dana te slabim koeficijentom korelacije. Najmanje zaostajanje, unutar jednog dana, utvrđeno je između oborina i vodostaja Plitvice. Analizama krivulja trajanja utvrđeno je da Plitvica gotovo u potpunosti drenira podzemne vode, izuzev piezometra 2178 u blizini kojega oko četvrtinu vremena prihranjuje vodonosnik.

Ključne riječi: korelacija, auto-korelacija i kros-korelacija, potok Plitvica, varaždinski aluvijalni vodonosnik

Corresponding author's address: Krešimir Pavlić, Faculty of Mining, Geology and Petroleum Engi-neering, University of Zagreb, Pierottijeva 6, 10000 Zagreb, Croatia; tel: +385 15535 931; fax: +385 1483 6051; e-mail: kresimir.pavlic@rgn.unizg.hr (ORCID: 0000-0003-3315-2900). 